Current Issues in Middle Level Education

Volume 25 | Issue 2

Article 5

2020

\title{
Simulating Collaboration in a Blended Course for Preservice Middle Grades Teachers: Attending to Team, Task, and Time
}

David C. Virtue

Western Carolina University, dvirtue@wcu.edu

Follow this and additional works at: https://digitalcommons.georgiasouthern.edu/cimle

Part of the Junior High, Intermediate, Middle School Education and Teaching Commons

\section{Recommended Citation}

Virtue, David C. (2020) "Simulating Collaboration in a Blended Course for Preservice Middle Grades Teachers: Attending to Team, Task, and Time," Current Issues in Middle Level Education: Vol. 25 : Iss. 2 , Article 5.

DOI: $10.20429 /$ cimle.2021.250205

Available at: https://digitalcommons.georgiasouthern.edu/cimle/vol25/iss2/5

This best practices is brought to you for free and open access by the Journals at Digital Commons@Georgia Southern. It has been accepted for inclusion in Current Issues in Middle Level Education by an authorized administrator of Digital Commons@Georgia Southern. For more information, please contact digitalcommons@georgiasouthern.edu. 
Virtue: Simulating Collaboration for Preservice Middle Level Teachers

\title{
Simulating Collaboration in a Blended Course for Preservice Middle Grades Teachers: Attending to Team, Task, and Time
}

\author{
David C. Virtue \\ Western Carolina University
}

\begin{abstract}
Collaboration and teamwork are essential aspects of the work of a professional middle level teacher and an integral part of AMLE Standard 5. Preservice teachers typically experience collaborative practices firsthand during field experiences, but the COVID-19 pandemic has caused many schools to shift instruction online thereby limiting the opportunities for teacher candidates to experience daily life in schools. Teacher educators can provide simulated opportunities for candidates to collaborate and engage in teamwork in virtual classroom settings. The author describes ways to simulate teacher collaboration in virtual settings by providing an example of engagements with teacher educators in a middle grades course with an emphasis on three aspects of planning: team, task, and time. The author reflects on the implementation of the simulation and offers recommendation for improvement.
\end{abstract}

\section{Introduction}

Collaboration and teamwork are essential aspects of the work of a professional teacher. Successful teachers must be able to plan instruction and assessments, analyze data, and problem solve with colleagues. The Interstate Teacher Assessment and Support Consortium (InTASC) teaching standards emphasize the importance of "a collaborative professional culture" among teachers:

Just as collaboration among learners improves student learning, we know that collaboration among teachers improves practice. When teachers collectively engage in participatory decision-making, designing lessons, using data, and examining student work, they are able to deliver rigorous and relevant instruction for all students and personalize learning for individual students. (Council of Chief State School Officers, 2013, p. 5)

Middle level teachers occupy particularly complex collaborative roles as classroom teachers, members of interdisciplinary teams, student advisors and advocates, and liaisons between the school and community. The Association for Middle Level Education (AMLE) teacher preparation standards account for this complexity and communicate clear expectations for candidates to collaborate successfully with colleagues and other constituencies as they carry out their professional responsibilities. For example, target performance for Standard 5: Middle Level Professional Roles includes the following expectations:

Middle level teacher candidates understand collaborative theories and processes and the interdependent relationships among all professionals who serve young adolescents (e.g., interdisciplinary teams, school counselors, social service workers, home-school coordinators, and community agencies). They initiate opportunities to collaborate with 
other professionals in ways that support and strengthen teaming practices and collaborative processes. (AMLE, 2012, p. 18)

Experiential approaches to learning are central to teacher education (Huss, 2007; Kaufman, 1996; Seed, 2008), and middle level teacher educators typically provide candidates opportunities to experience collaboration and teamwork through practica and field work in clinical settings (Howell, Carpenter, \& Jones, 2016). When teacher educators do not have access to clinical settings, they may create authentic learning experiences (Newmann, Marks, \& Gamoran, 1996) in the university classroom to approximate middle level teacher practices as preservice candidates might enact them in the field. Simulations, role-playing, and modeling are effective methods for providing authentic learning experiences in professional programs like teacher education (Leamana \& Flanagana, 2013; Ward, Williams, \& Hancock, 2006), and simulations have long been used in teacher education to help teacher candidates improve their skills and experience the real world of teaching (e.g., Cruickshank, 1969; Chisholm, 1994; Huss, 2007; Landon-Hays et al., 2020; Ziegenfuss, 2011; Zuckerman, 1979).

Though middle level teacher educators have long known how to provide authentic, experiential opportunities for candidates to learn collaborative practices in both clinical settings and university classroom settings (e.g., Wilson, 2007), COVID-19 has disrupted these and other in-person learning modalities as P-12 schools and universities have shifted to online and remote teaching. The pandemic has put middle level teacher educators on a "steep learning curve" (Nagle \& Bishop, 2020, p. 1) and thrust them into what Eisenbach et al. (2020) called "emergency remote teaching" (p. 5). Under these conditions and constraints, teacher educators must find ways for teacher candidates to experience firsthand the characteristics of successful middle level schools described in the middle level literature (e.g., Bishop \& Harrison, 2020).

In this article, I describe how I used student groupings in a blended course to provide opportunities for middle level preservice teachers to experience collaboration and teamwork. I planned a series of curricular conversations (Mills, 2001) about tiering assessments that occurred in breakout rooms during an online class session. I purposefully assigned candidates to groups that simulated content area departments, interdisciplinary teams, and a whole-group school faculty. Planning and implementing the simulation required careful attention to three elements: team, task, and time.

\section{Simulated Collaboration and Teamwork in an Online Class}

\section{The Context}

The middle grades education program at Western Carolina University (WCU) is a CAEPaccredited program that prepares candidates to teach young adolescents in grades 6 through 9 . The program allows candidates to specialize in language arts, mathematics, science or social studies and leads to a Bachelor of Science in Education (B.S.Ed.) degree along with an initial teaching license.

The lesson I describe in this article was implemented in a course on responsive assessment and classroom management that teacher candidates take the semester before student teaching. Candidates enroll concurrently in a three-credit supervised internship and a two-credit seminar in responsive teaching. During the fall of 2020, the course met on campus twice weekly for 75-minute sessions. 
Normally, my face-to-face pedagogy would include small group engagements during each session (e.g., pair-share, small group discussions). However, WCU's social distancing protocols limited our ability to engage in small groups. We decided to conduct some class sessions online to overcome this obstacle. WCU used Zoom as a platform for online learning, and because Zoom has breakout room functions it enabled me to arrange groupings analogous to those I would normally plan in the classroom. Also, because all the middle grades schools in the area were delivering instruction in online or blended modalities, I realized the candidates in my course were not experiencing many aspects of daily school life, including collaborative planning. Through Zoom breakout rooms, I believed I could simulate some of the collaborative interactions that might normally occur in a middle level school.

We used Rick Wormeli's (2018) book, Fair Isn't Always Equal, as the main course text. The lesson described in this article was intended to allow candidates to apply and extend their understanding of chapter eight focused on tiering assessments. Wormeli defined tiering as follows: "To adjust a lesson, an assignment, or an assessment to a developmentally appropriate level of readiness for students; most often done by increasing or decreasing the complexity of a task, not the workload or difficulty of a task" (p. 284). The engagements I planned were intended to allow candidates to apply tiering principles to assessments they had already planned for other courses.

I considered three important elements in my planning: team, task, and time. Team refers to the types of grouping arrangements used, while task refers to the planned substance and structure of interactions among candidates within and between groups. Time considerations include the planned intervals for each component of the lesson as well as the overall pace of the lesson. During our first Zoom class session, we had established the following norms to help facilitate an orderly, respectful learning environment:

- Hold up a hand or finger to be recognized.

- Please be patient and gracious - don't talk over one another.

- Use the chat tool to pose a question or make a comment.

- Remember to check the recipient in chat (i.e., "Everyone" or a specific person).

Members of the class followed the norms, which generally reflected the norms they had established in their online and blended middle grades internship classes.

\section{Team}

I structured the lesson to provide candidates opportunities to experience three types of simulated collaborative groups: content area specialty groups, or "departments," interdisciplinary teams, and a whole-school faculty meeting. The class had eight candidates representing three content area specializations: language arts $(n=2)$, mathematics $(n=2)$, and social studies $(n=$ 4). No candidates were specializing in science. Therefore, only three departmental groups met, and the two interdisciplinary teams had four members with no science teacher and two social studies teachers. Candidates were placed in five different schools for their supervised internship, so I tried to ensure the teams had balanced representation of members from different clinical sites so they could draw on their diverse experiences. 


\section{Task}

I began the class by reviewing ways teachers may tier assessments for different levels of challenge, highlighting the following key points emphasized by Wormeli (2018):

- Adjust levels of challenge; increase/decrease complexity.

- Ask students to "interact with topics more deeply, more divergently, in more breadth, or by weaving the topic with other ideas" (p. 91).

- Begin with the assumption that all students will demonstrate proficiency with the standard.

- Understand the gradations of mastery for the learning goal. What are the learning progressions for this content? [Emphasis added.]

- Do not assume there will always be three tiers-your students' readiness levels determine the tiers - and not all aspects of a lesson need to be tiered.

- Begin tiering by focusing on one concept or task.

The class also considered some specific strategies for tiering: (a) using frameworks like Bloom's levels of understanding, Webb's depth of knowledge, Williams' Taxonomy of Creative Thinking, or Tomlinson's equalizer to inform planning; (b) using contracts with clear expectations and checkpoints, as appropriate, to vary content mastery and work completion requirements; (c) using learning menus, game boards, or cubing to offer varied levels of challenge, and using summarization pyramids or RAFT(S) to provide structured support and choices.

After reviewing this background material, I shared a framework for carrying out "curricular conversations" recommended by Mills (2001). The five components of the framework would serve as a guide for our class session:

1. Wondering (What are our burning questions?)

2. Looking closely (What do focused observations reveal about our wonderings?)

3. Making new connections (How do we interpret or make sense of what we observe?)

4. New questions (What new wonderings grow from our sense making?)

5. Making informed predictions (What new plans or curricular decisions might follow from our sense making?)

In the context of this lesson, our wondering would center on the question: How do we effectively tier (or adjust the complexity of) learning tasks and assessments based on students' readiness? Looking closely would involve the examination of learning tasks and assessments in lessons candidates had already planned either for their current internships or for past courses. They each submitted two sample lessons before our class meeting. Based on this examination of our lessons, the class would make new connections to ideas and concepts from the Wormeli (2018) text, other courses, and their classroom experiences so they could collaboratively generate ideas for tiering. After generating tiering ideas, candidates would reflect on their ideas, raising new questions about tiering and making informed predictions about practice so they could adjust the ideas, as appropriate. 
The curricular conversations occurred in three phases. Each phase corresponded to one of the three collaborative grouping arrangements I aimed to simulate: content area departments, interdisciplinary teams, and whole-school faculty.

Phase 1: Department groupings. The first phase occurred in groups that simulated academic department meetings in a middle level school. I placed candidates in Zoom breakout rooms according to content area specialization (e.g., language arts, mathematics, or social studies). In the breakout rooms, each member gave an oral overview of their sample lessons and then discussed any plans for tiering based on students' levels of readiness. After each person shared, the group generated new or refined ideas for tiering. I provided the following list of questions to help guide the conversations:

- How will you preassess to determine levels of readiness?

- Why do you think the tiering ideas will work?

- Do your tiering ideas address different depths of knowledge or levels of understanding discussed in Wormeli (2018)?

- Have you tried any of these tiering strategies before or seen them in practice?

Phase 2: Interdisciplinary team groupings. The second phase of the curricular conversations occurred in groups that simulated interdisciplinary teams. Candidates were placed in two Zoom breakout rooms, each with a person who had language arts, mathematics, and social studies as a specialty area. Using a jigsaw approach (Aronson et al., 1978), each team member gave an overview of one of their department colleagues' lessons and then share the plans they discussed for tiering based on students' readiness. After each team member shared, the group discussed ideas for refining the tiering strategies. During the team phase, candidates also discussed the following questions adapted from Wormeli (2018, p. 108):

- How do we assign equitable grades when different tierings are used?

- Do we let advanced students get by with doing less complex work occasionally?

- Can students occasionally negotiate the level at which they are asked to perform?

Phase 3: Whole-school faculty group. The third phase of the curricular conversations occurred in a whole group that simulated a school faculty meeting. We discussed characteristics of innovative ideas for tiering generated during the departmental and interdisciplinary team conversations, and we also discussed whether any of the ideas might be adopted by a team or school for implementation. The whole-group discussion allowed us to refine and extend ideas from the earlier conversations.

\section{Time}

Time was an important consideration throughout the lesson. The class session lasted 75 minutes, so pacing was critical to allow adequate time for the review of background information at the start of the session and time for rich discussion during the breakouts. I had planned for 15 minutes to launch the lesson and provide background information, 20 minutes each for the departmental and interdisciplinary team discussions, 15 minutes for the whole-group faculty meeting, and 5 minutes for lesson closure. 


\section{Reflection and Recommendations}

The collaborative groupings allowed for rich conversations about tiering and related topics, such as differentiation, student engagement, and curriculum integration. While I did not conduct formal research on the impact of the simulation, I can share anecdotal insights about the value of the experience. Candidates appreciated the opportunity to examine and discuss each other's work and to talk about common challenges they had experienced trying to tier assessments and differentiate instruction in their internships. One of the conversations in the social studies team addressed heterogeneous grouping arrangements and opportunities they provide for peer-mediated learning. Another candidate posited that student engagement is the first rung on the tiering ladder and then applauded a peer's ideas for using relationship-building strategies to spark student engagement. Yet another popular idea involved using a workshop approach to foster targeted formative assessment that can inform individualized instruction.

While I was pleased with the level of engagement the candidates demonstrated, I was disappointed that the interdisciplinary team discussion seemed to be cut short. In hindsight, I might have assigned some of the background readings (e.g., the curricular conversations framework) as homework, thereby allowing me to reallocate time during class to the breakouts. In future iterations of this simulation I will also consider assigning roles during the breakouts (e.g., department chair or team leader) to ensure everyone stays engaged, the workload is balanced, and candidates are held accountable for their learning. More clearly defined roles and responsibilities will enhance links between the simulation and middle level school realities.

My reflection on the tiering lesson yielded three recommendations for teacher educators who seek to simulate collaboration and teamwork in an online classroom. First, teacher educators need to be purposeful when they assign candidates to teams. Team groupings should mirror the types of collaborative arrangements candidates may experience in middle level schools. The example I shared simulated content area departments, interdisciplinary teams, and a wholeschool faculty. Other types of simulated groupings might include IEP teams, co teaching dyads that pair a content teacher with a special education or ESOL teacher, or special committees (e.g., textbook selection panel).

Second, teacher educators need to communicate clear task instructions and establish clear norms for participating in an online classroom. Researchers have found that teachers can learn effectively in peer learning environments if they perceive them to be safe and constructive (Hawkey, 1995; Zwart et al., 2009). Norms for participation, such as hand-raising and turntaking procedures, can help optimize peer-to-peer interactions and ensure the learning environment is positive so learners can complete tasks efficiently and successfully. Teacher educators can consult a growing literature about effective online teaching to help them establish norms and foster a constructive learning environment (see, e.g., Kashdan, 2020a, 2020b, 2020c). For this lesson, I found it was helpful to provide task instructions in multiple formats - oral and written - and to distribute copies of instructions to each learner to ensure individual accountability for task completion.

Finally, teacher educators need to be realistic about the amount of time candidates need to complete tasks in groups. While it is possible to structure intra-group interactions and assign roles in ways that help candidates complete tasks within a given timeframe, it is also important to be flexible. Sometimes unanticipated, but productive, turns in a discussion can provide powerful opportunities for learning. In hindsight, 20 minutes was not enough time for the departmental 
and interdisciplinary team meetings. Candidates were eager to share their work with one another and the conversations that ensued were rich and generative. In the future, I will either reallocate more time for these aspects of the simulation or spread the work across two class sessions.

\section{Conclusion}

The COVID-19 pandemic has disrupted education in ways that have profoundly impacted the preparation of middle level teachers. School-based clinical placements normally provide teacher candidates opportunities to experience firsthand middle level professional roles and many aspects of day-to-day life in middle level schools. Such experiences are critical as candidates learn to "understand the specialized professional roles they play in middle level education [and] demonstrate their capabilities to perform successfully in these roles" (AMLE, 2012, p. 16). However, the shift to online and blended learning has limited or eliminated opportunities for teacher candidates to gain some of these experiences.

Teacher educators can simulate some aspects of life in middle level schools in the university classroom - even if the classroom is virtual. In this article, I described a lesson in which I simulated three types of groupings - content area departments, interdisciplinary teams, and a whole-school faculty - and I highlighted the importance of considering team, task, and time in the planning process. While there is no substitute for teacher candidate learning that is embedded in middle level schools and classrooms, this example represents just one small way teacher educators can approximate aspects of clinical experiences in a simulated environment.

\section{References}

Aronson, E., Blaney, N., Stephan, C., Sikes, J., Snapp, M. (1978). The jigsaw classroom. Sage.

Association for Middle Level Education. (2012). Association for Middle Level Education Middle Level Teacher Preparation Standards with Rubrics and Supporting Explanations. Author. Retrieved from: http://www.amle.org/portals/0/doc/standards/2012_AMLE_Standards.doc

Bishop, P. A., \& Harrison, L. M. (2020). The successful middle school: This we believe. Association for Middle Level Education.

Chisholm, I. M. (1994, Winter). Preparing teachers for multicultural classrooms. The Journal of Educational Issues of Language Minority Students, 14, 43-68.

Council of Chief State School Officers. (2013, April). Interstate Teacher Assessment and Support Consortium InTASC Model Core Teaching Standards and Learning Progressions for Teachers 1.0: A Resource for Ongoing Teacher Development. Author. Retrieved from: https://ccsso.org/sites/default/files/201712/2013_INTASC_Learning_Progressions_for_Teachers.pdf

Cruickshank, D. R. (1969). The use of simulation in teacher education: A developing phenomenon. Journal of Teacher Education, 20(1), 23-26.

Eisenbach, B. B., Greathouse, P., \& Acquaviva, C. (2020). COVID-19, middle level teacher candidates, and colloquialisms: Navigating emergency remote field experiences. Middle 
Grades Review, 6(2), 1-5. Available at:

https://scholarworks.uvm.edu/mgreview/vol6/iss $2 / 2$

Hawkey, K. (1995). Learning from peers: The experience of student teachers in school-based teacher education. Journal of Teacher Education, 46(3), 175-183.

Howell, P. B., Carpenter, J., \& Jones, J. (2016). Concluding thoughts. In P. B. Howell, J. Carpenter, \& J. Jones (Eds.), Clinical preparation at the middle level: Practices and possibilities (pp. 297-298). Information Age.

Huss, J. (2007). Using constructivist teaching to shift the paradigm for pre-service philosophy of education statements. Essays in Education, 21, 61-76.

Kashdan, T. B. (2020a). Nine strategies to optimize your online classroom. Part I. Psychology Today [Blog post]. Retrieved from: https://www.psychologytoday.com/us/blog/curious/202004/nine-strategies-optimizeyour-online-classroom

Kashdan, T. B. (2020b). 7 more strategies to optimize online classrooms. Part II. Psychology Today [Blog post]. Retrieved from: https://www.psychologytoday.com/us/blog/curious/202004/7-more-strategies-optimizeonline-classrooms

Kashdan, T. B. (2020c). Final strategies to optimize online classrooms. Part III. Psychology Today [Blog post]. Retrieved from: https://www.psychologytoday.com/us/blog/curious/202004/final-strategies-optimizeonline-classrooms

Kaufman, D. (1996). Constructivist-based experiential learning in teacher education. Action in Teacher Education, 18(2), 40-50.

Landon-Hays, M., Peterson-Ahmad, M. B., \& Frazier, A. D. (2020). Learning to teach: How a simulated learning environment can connect theory to practice in general and special education educator preparation programs. Education Sciences, 10(184), 1-17. doi:10.3390/educsci10070184

Leamana, L. H., \& Flanagana, T. M. (2013). Authentic role-playing as situated learning: Reframing teacher education methodology for higher-order thinking. Studying Teacher Education: A Journal of Self-study of Teacher Education Practices, 9(1), 45-61.

Mills, H. (2001). When teachers have time to talk: The value of curricular conversations. Language Arts, 79(1), 20-28.

Nagle, J. F., \& Bishop, P. A. (2020). Middle grades education in the age of COVID-19: Editorial remarks. Middle Grades Review, 6(2), 1-3. Available at: https://scholarworks.uvm.edu/mgreview/vol6/iss $2 / 1$

Newmann, F. M., Marks, H. M., \& Gamoran, A. (1996). Authentic pedagogy and student performance. American Journal of Education, 104(4), 280-312.

Seed, A. H. (2008). Cohort building through experiential learning. Journal of Experiential Education, 31(2), 209-224. 
Ward, P., Williams, A. M., \& Hancock, P. A. (2006). Simulation for performance and training. In K. A. Ericsson, N. Charness, P. J. Feltovich, \& R. R. Hoffman (Eds.), The Cambridge handbook of expertise and expert performance (pp. 243-262). New York, NY: Cambridge University Press.

Wilson, J. L. (2007). Virtual teaming: Placing middle level teachers on interdisciplinary teams. Research in Middle Level Education Online, 31(3), 1-15.

Ziegenfuss, R. G. (2011). Modeling alternative assessment for pre-service middle level teachers. Current Issues in Middle Level Education, 16(2), 13-22.

Zuckerman, R. A. (1979). Simulation helps preservice students acquire pragmatic teaching skills. Journal of Teacher Education, 30(4), 14-16.

Zwart, R. C., Wubbels, T., Bergen, T., \& Bolhuis, S. (2009). Which characteristics of a reciprocal peer coaching context affect teacher learning as perceived by teachers and their students? Journal of Teacher Education, 60(3), 243257. 